\section{Genome Size of Pecan as Determined by Flow Cytometry}

\author{
L.J. Grauke ${ }^{1}$ \\ USDA-ARS Pecan Breeding \& Genetics, Rt. 2, Box 133, Somerville, TX 77879
}

H.J. Price ${ }^{2}$

Department of Soil \& Crop Sciences, Texas A\&M University, College Station, TX 77843

\section{J.S. Johnston ${ }^{3}$ \\ Department of Entomology, Texas A\&M University, College Station, TX 77843}

Additional index words. Carya illinoinensis

Knowledge of the amount of nuclear DNA in a plant's cells contributes to an understanding of the genome of that organism, and allows comparison with other organisms of known genome size. The size of the unreplicated haploid genome, or $1 \mathrm{C}$ value is used to characterize species. The $1 \mathrm{C}$ value, expressed in picograms (pg), may be converted to an estimate of the number of megabase pairs (Mbp). One picogram equals $\approx 960 \mathrm{Mbp}$. Species vary widely in genome size, from about $0.2 \mathrm{pg}$ for Arabidopsis thaliana L. (which makes an excellent model system due to small genome size) to $\approx 90 \mathrm{pg}$ in Fritillaria davisii Turrill (Bennett and Smith, 1976). Furthermore, closely related species may vary greatly in genome size (Price, 1976). To our knowledge, there has been no previous report of genome size in the walnut family Juglandaceae. The purpose of this work was to determine the genome size of pecan, Carya illinoinensis $(2 n$ $=32$ ), as a component in the development of a molecular genetics research strategy.

Samples of nuclei for flow cytometry were obtained from newly expanded pecan leaves ('Bryzozski-Vlasek', CSV 14-12), the distal 5 $\mathrm{mm}$ of root tips ('Little Jewel' seedling rootstock) and embryos from mature seeds (selection 74-20-16, CSC 7-1). Pecan tissue was chopped together with a leaf of Pisum sativum var. Minerva Maple using a new razor blade in a modified Galbraith et al. (1983) buffer as described by Johnston et al. (1999). The buffer consisted of (per 1), $4.26 \mathrm{~g} \mathrm{MgCl}_{2}, 8.84 \mathrm{~g}$ sodium citrate, $4.2 \mathrm{~g}$ 3-[morpholino]propane sulfonic acid, $1 \mathrm{~mL}$ Triton X-100, $1 \mathrm{mg}$ boiled ribonuclease $\mathrm{A}, \mathrm{pH}$ 7.2. The resulting slurry was filtered through a $53-\mu \mathrm{m}$ nylon filter, and propidium iodide (PI) was added to a final concentration of $50 \mathrm{mg} \cdot \mathrm{kg}^{-1}$. The stained samples were stored in the dark on ice and analyzed by flow cytometry after $1 \mathrm{~h}$. The flow

Received for publication 11 Nov. 2000. Accepted for publication $10 \mathrm{Feb} .2001$. The cost of publishing this paper was defrayed in part by the payment of page charges. Under postal regulations, this paper therefore must be hereby marked advertisement solely to indicate this fact.

${ }^{1}$ Research Horticulturist and Curator, National Clonal Germplasm Repository for Pecans and Hickories. ${ }^{2}$ Professor.

${ }^{3}$ Professor.

detected with a photomultiplier screened long pass filter. Offset and linearity of the flow cytometer were checked with fluorescent check beads (Coulter Electronics) as recommended by the manufacturer. The mean 2C DNA content of pecan nuclei was calculated by the formula: DNA content $=$ (mean fluorescence pecan/mean fluorescence pea) (mean DNA content of the pea standard). The 2C DNA content of pea is $9.56 \mathrm{pg}$ (Johnston et al., 1999).

Samples from pecan root and embryo produced distinct and consistent peaks, while leaf tissue did not. Genome sizes (2C) estimated from $2 \mathrm{C}$ root $(1.64 \mathrm{pg})$ and embryo nuclei $(1.66,1.68$ and $1.69 \mathrm{pg}$; mean $=1.68 \mathrm{pg})$ were similar. The mean $2 \mathrm{C}$ genome size of pecan, therefore, is $\approx 1.7 \mathrm{pg}(1 \mathrm{C}=0.85 \mathrm{pg}$ or 816 Mbp). This is comparable to the genome size of certain species of oak (Quercus petraea (Matt.) Liebl., $1 \mathrm{C}$ value $=0.80 \mathrm{pg}$ ) (Bennett and Smith, 1991), but much larger than the diploid peach, Prunus persica (L.) Batsch ( $2 n$ $=16,1 \mathrm{C}$ value $=0.28 \mathrm{pg})($ Bennett and Leitch, 1995). The genome of the hexaploid plum, Prunus domestica L. $(6 n=48,1 \mathrm{C}$ value of $0.92 \mathrm{pg}$ ) (Bennett and Leitch, 1995) is only slightly larger than that of pecan. visualized against background noise (E).
Genome size has taxonomic value and may have importance for the characterization of diversity in the National Clonal Germplasm Repository collections. The technique reported here may be applied to accessions of related species to assess patterns of genome size differences related to patterns of polyploidy. Repository Provenance collections (populations of pecan collected across the range of the species) could be evaluated for genome size to determine the extent of intraspecific variation in the trait, which in other species has been linked to drought tolerance (Wakamiya et al., 1993). One of the most practical applications of the genome size information is in the development and evaluation of DNA clone libraries. Knowledge of genome size is necessary to determine the number of known-size fragment clones required, at a given probability, in order to have coverage of all DNA sequences represented in a genome library (Clarke and Carbon, 1976).

\section{Literature Cited}

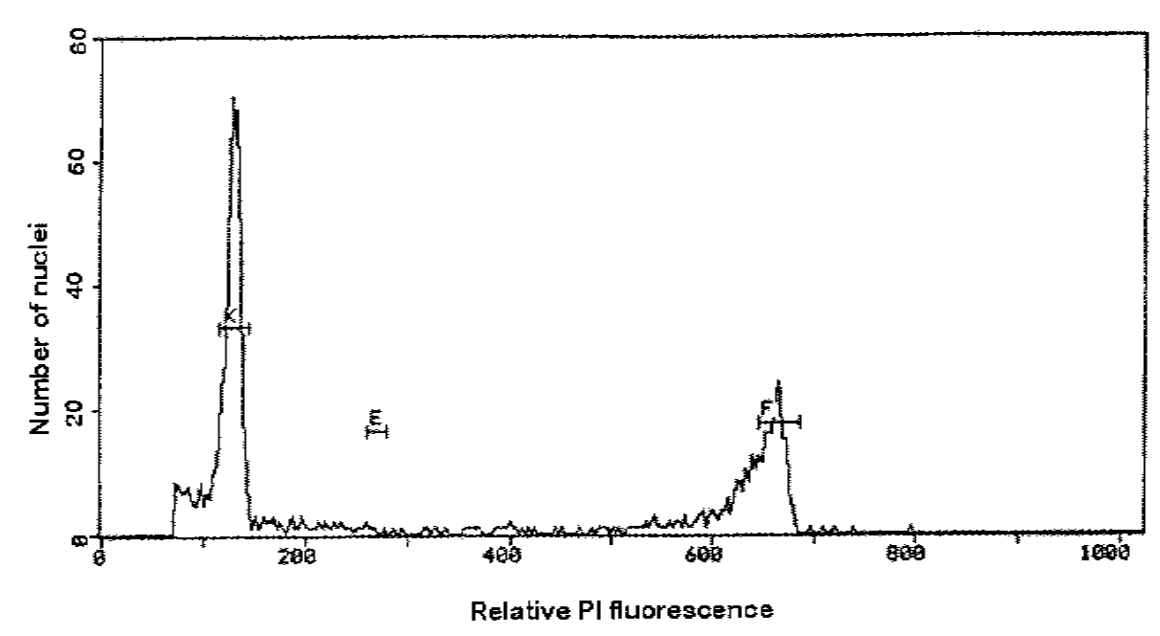

Fig. 1. Relative red fluorescence of PI-stained nuclei from pecan embryo (K), and pea leaves $(\mathrm{F})$ as

Bennett, M.D. and J.B. Smith. 1976. Nuclear DNA amounts in angiosperms. Philosophical Transactions of the Royal Society of London B 274:227-274

Bennett, M.D. and J.B. Smith. 1991. Nuclear DNA amounts in angiosperms. Philosophical Transactions of the Royal Society of London B 334:309-345.

Bennett, M.D. and I.J. Leitch. 1995. Nuclear DNA amounts in angiosperms. Ann. Bot. 76:113-176.

Clarke, L. and J. Carbon. 1976. A colony bank containing synthetic Col E1 hybrid plasmids representative of the entire $E$. coli genome. Cell 9:91-100.

Galbraith D.W., K.R. Harkins, J.M. Maddox, N.M. Ayres, D.P. Sharma, and E. Firoozabady. 1983. Rapid flow cytometric analysis of the cell cycle in intact plant tissues. Science 220:1049-1051.

Johnston, J.S., M.D. Bennett, A.L. Rayburn, D.W. Galbraith, and H.J. Price. 1999. Reference standards for determination of DNA content of plant nuclei. Amer. J. Bot. 86: 609-613.

Price, H.J. 1976. Evolution of DNA content in higher plants. Bot. Rev. 42:27-52.

Wakamiya, I., R.J. Newton, J.S. Johnston, and H.J. Price. 1993. Genome size and environmental factors in the genus Pinus. Amer. J. Bot. 80:12351241. 